Volume 4, Nomor 1, 2021, hlm. 17-30

P-ISSN: 2622-2280 | E-ISSN: 2622-4658

https://ejurnal.iiq.ac.id/index.php/alfanar

DOI: 10.33511/alfanar.v4n1.17-30

\title{
Analisis Surat Al-Anfāl Ayat 17: Upaya Mengungkap Sisi Transendental Hermeneutika Double Movement
}

\author{
Miatul Qudsia dan Muhammad Faishal Haq \\ UIN Sunan Ampel Surabaya \\ miatulqudsia@gmail.com danFaizical98@gmail.com
}

\begin{abstract}
The study of the Koran from a contextual point of view continues to grow. One of the offers that has been continuously studied and applied is the double movement theory initiated by Fazlur Rahman and developed by Abdullah Saeed. The double movement theory emphasizes the socio-historical context of the Koran and the present. To bridge the two periods, a researcher must sensitively take the meaning of the verse being studied or what is called the moral ideal. Thus, the meaning of the purpose of the revelation of the Qur'anic verse will continue to be conveyed at any time. The object of the application of the double movement is indeed law verses, so as to produce a moral ideal that is real or concrete. However, in this study, the researcher found that double movement not only produces concrete moral ideals, but also transcendental ones. The verse studied is the verse of war, surah alAnfäl verse 17. So that, the result is that the moral ideal which is concrete from this verse is that it is permissible and even required to take the path of war if it is in an emergency and is depressed. For example, there is pressure, discrimination and so on that cause torture. And, the transcendental moral ideal is that there must be an attitude of tawakal and endeavor from every Muslim. That Allah can make real what is considered impossible by humans.
\end{abstract}

Keywords: Badar, Double Movement, Ideal Moral, Concrete, Trancendental

\begin{abstract}
Abstrak
Kajian terhadap Al-Qur'an dengan sudut pandang kontesktual kian terus berkembang. Salah satu tawaran yang hingga ini terus ditelaah dan diaplikasikan adalah teori double movement yang digagas oleh Fazlur Rahman, dan dikembangkan oleh Abdullah Saeed. Teori double movement sangat menitikberatkan konteks sosio-historis Al-Qur'an dan masa sekarang. Untuk menjembatani antara dua masa tersebut, maka seorang peneliti harus secara peka mengambil makna dari ayat yang dikaji atau yang disebut dengan ideal moral. Dengan demikian, makna dari tujuan diturunkannya ayat Al-Qur'an tersebut akan tetap tersampaikan hingga kapanpun. Obyek dari pengaplikasian double movement memang ayat-ayat hukum, sehingga menghasilkan ideal moral yang sifatnya nyata atau konkret. Namun, dalam penelitian ini, peneliti menemukan bahwa double movement tidak hanya menghasilkan ideal moral yang sifat konkret tapi juga transendental. Ayat yang dikaji adalah ayat perang, surat al-Anfāl ayat 17. Sehingga, dihasilkan bahwa Ideal moral yan bersifat konkret dari ayat ini adalah dibolehkan bahkan diharuskan mengambil jalur peperangan jika sudah dalam keadaan darurat dan tertekan. Seperti, adanya tekanan, pendiskriminasian dan lain sebagainya yang menyebabkan ketersiksaan. Dan, ideal moral yang bersifat transendental adalah harus adanya sikap tawakal dan ikhtiar dari setiap muslim. Bahwa Allah dapat menjadikan nyata setiap apa yang dianggap mustahil oleh manusia.
\end{abstract}

Kata Kunci: Badar, Double Movement, Ideal Moral, Konkret, Transendental 


\section{PENDAHULUAN}

Mengungkap pesan yang terkandung dalam ayat Al-Qur'an tidak bisa hanya terpaku pada teks ayat saja. Analisis terhadap konteks dimana ayat itu diturunkan, juga penting untuk ditelaah. Hal tersebut tidak lain untuk mendapatkan pemahaman dan ketepatan dalam menafsirkan.

Konteks sosio-historis Al-Qur'an, baik pada masa pra-Islam maupun periode awal tidak bisa dikesampingkan. Untuk mendapatkan pemahaman yang demikian, maka harus mengetahui bagaimana kehidupan Nabi Muhammad Saw. ${ }^{1}$ di Mekkah maupun Madinah, ekonomi, politik, adat serta nilai-nilai yang berlaku, terutama di wilayah Hijaz. $^{2}$

Kajian semacam itu dalam 'ulūm Al-Qur'ān dikenal dengan sabab nuzūl. Menurut Muhammad Chirzin, dengan adanya sabab nuzūl, setidaknya menjadi bukti bahwa ayatayat Al-Qur'an mempunyai relasi dialektis dengan fenomena sosio-kultural masyarakat pada waktu itu. ${ }^{3}$

Sabab nuzūl dalam pembahasan 'ulūm Al-Qur'ān memang menempati posisi yang fundamental. Namun, menjadi problematik ketika hanya berpaku pada periwayatan sabab nuzūl. Seperti yang diutarakan oleh Syahrur, menurutnya, keterpakuan pada keberadaan sabab nuzūl justru akan mengurangi nilai universalitas dari Al-Qur'an. Sebab, sabab nuzūl adalah periwayatan yang merekam peristiwa secara temporal. ${ }^{4}$

Lebih lanjut, Saeed juga mengomentari, bahwa sabab nuzūl hanya memberikan pemahaman yang terbatas pada konteks sosia-historis. Apalagi, tidak sedikit riwayat yang bisa saja saling bertentangan. ${ }^{5}$ Dan, terkadang kualitas hadisnya pun masih dipertanyakan.

Dalam artikel ini, peneliti membedah satu ayat yakni surat al-Anfāl ayat 17 yang berkaitan dengan Perang Badar. Tentunya, ayat ini dibedah menggunakan kajian sabab $n u z \bar{u} l$ serta kajian historis yang bersinggungan tepat dengan peristiwa Perang Badar. Namun, peneliti hendak memberikan satu hasil yang berbeda dengan menggunakan pendekatan hermeneutika double movement.

Selama ini, kajian-kajian terkait double movement terfokuskan untuk mengungkap sisi-sisi konkret dari ayat-ayat hukum-hukum. Hal ini memang kajiannya difokuskan pada

1 Seperti yang dijelaskan Abdullah Saeed, bahwa kehidupan Nabi Muhammad Saw. secara keseluruhan adalah bagian dari konteks. Maka, sejarah yang melingkupi Nabi Muhammad Saw. tersebut juga menjadi bagian penting dalam setiap kajian ke-Al-Qur'anan. Lihat, Abdullah Saaed, Pengantar Studi Al-Qur'an, Terj. Shulkhah dan Sahiron Syamsudin (Yogyakarta: Baitul Hikmah Press, 2016), h. 9-18.

2 Abdullah Saaed, Paradigma, Prinsip dan Metode Penafsiran Konteksualis Al-Qur'an, Terj. Lien Iffah Naf'atu Fina dan Ari Henri (Yogyakarta: Baitul Hikmah Press, 2017), 213.

${ }^{3}$ Muhammad Chirzin, Mengerti Asbabun Nuzul; Rampai Peristiwa dan pesan Moral di Balik Ayat-Ayat Suci Al-Qur'an (Jakarta: Zaman, 2015), h. 18.

${ }^{4}$ Irma Riyani, “Reinterpretasi Asbāb al-Nuzūl bagi Penafsiran Al-Qur'an,' Wawasan: Jurnal Ilmiah Agama dan Sosial Budaya" 2, no. 1 (2017), h. 18. Lihat Naḥw Uṣūl Jadīdah li al-Fiqh AlIslāmī karya Muhammad Syahrur.

5 Abdullah Saeed, Pengantar Studi Al-Qur'an, Terj. Shulkhah dan Sahiron Syamsudin (Yogyakarta: Baitul Hikmah Press, 2016), h. 2.

18 | Al-Fanar: Jurnal Ilmu Al-Qur'an dan Tafsir 
ayat-ayat ethico-legal, yakni berkaitan dengan etika, moral, serta hukum maupun sosial. ${ }^{6}$ Sebagaimana yang dipapakan oleh Abdullah Saeed. Dan dalam perkembangannya, banyak atau mungkin hampir dari seluruh penelitian yang menggunakan metode hermeneutika double movement ini pada akhirnya akan memberikan kesimpulan terkait produk hukum dengan melihat ideal moral ayatnya. Yang dalam hal ini penulis menyebutnya sebagai hasil yang konkret.

Ini dapat dilihat dari beberapa penelitian, sebagai contoh penelitian yang dilakukan oleh Labib Muttaqin, dengan judul "Aplikasi Teori Double Movement Fazlur Raman Terhadap Dotrin Kewarisan Islam Klasik". Dari judul sudah dapat diketahui bahan penelitian tersebut titik fokusnya adalah tentang waris. Penulis menyoal ulang terait hukum waris antara laki laki dan perempuan, yang awalnya $2: 1$ menjadi $1: 1 .^{7}$

Kemudian, penelitian yang dilakukan oleh Zunly Nadia yang berjudul "Membaca Ayat Poligami Bersama Fazlur Rahman”. Penelitian ini berangkat dari permasalahan yang sering dijumpai di masyarakat, yakni menggunakan ayat yang berbicara tentang poligami sebagai legitimasi untuk melakukan poligami. Padahal, menurut penulis tersebut, ketika ayat-ayat poligami tersebut dibaca menggunakan hermeneutika double movement akan memberikan pemahaman yang berbeda. Ayat-ayat poligami tersebut justru untuk menyelesaikan masala kemanusiaan, bukan sebegai legitimasi untuk memudahkan seseorang berpoligami. ${ }^{8}$

Selanjutnya adalah penelitian yang dilakukan oleh Aas Siti Aisyah dengan judul "Reinterpretasi Ayat-Ayat Qisas dengan Metode Double Movement". Dari penelitiannya tersebut, penulis berupaya untuk memberikan tafsiran ulang dan menelisik lebih dalam apa makna serta ideal moral yang terkandung dalam ayat-ayat yang menjelaskan tentang qisas. Hal ini untuk menjauhkan pembaca dari kesalahpahaman memahami ayat-ayat qisas. Hasil dari penelitian tersebut menyatakan bahwa salah satu ideal moral dari ayat-ayat qisas adalah justru untuk melindungi HAM. Namun jika itu bekaitan dengan hukuman, pemerintah harus berdasarkan pada undang-undang yang telah disepakati dan secara adil. ${ }^{9}$

Lalu, penelitian oleh Ahmad Ali Masyhuda dengn judul "Pengaplikasian Teori Double Movementpada Hukum 'Iddah untuk Laki-Laki”. Dalam penelitiannya ini, penulis bertujuan untuk menelaah apakah seorang lelaki juga mempunyai masa 'iddah sama seperti halnya perempuan. Sebab, selama ini kajian yang ada terus mengaitkan masa 'iddah dengan perempuan. Dari hasil penelitiannya tersebut, penulis menyimpulkan bahwa masa 'iddah memang hanya ditujukan kepada perempuan. Karena hal itu

\footnotetext{
${ }^{6}$ Abdullah Saeed, Al-Qur'an Abad 21: Tafsir Kontekstual, Terj. Ervan Nurtawab (Bandung: Mizan, 2016), h. 17. Lihat juga, Muhammad Faishal Haq dan Miatul Qudsia, "Revitalisasi Hermeneutika Sebagai Pendekatan Tafsir (Kajian Hermeneutika Abdullah Saeed)," Miyah: Jurnal Studi Islam, 16, no. 01 (2020),h. 8-9.

7 Labib Muttaqin, "Aplikasi Teori Double Movement Fazlur Rahman Terhadap Doktrin Kewarisan Islam Klasik”, Al-Manahij; Jurnal Kajian Hukum Islam 7, no. 2 (2013), h. 195-206.

${ }^{8}$ Zunly Nadia, "Membaca Ayat Poligami Bersama Fazlur Rahman," Mukaddimah: Jurnal Studi Islam 2, no. 2 (2018), h. 203-28.

9 Riyani, "Reinterpretasi Asbāb al-Nuzūl bagi Penafsiran Al-Qur'an", Skripsi UIN Sunan Gunung Djati Bandung, (2019), h.1-110.
} 
bertujuan untuk melihat kekosongan rahim seorang istri. Sedangkan untuk seorang suami memang ada masa tunggu untuk menikah lagi, yang Ulama klasik menyebutnya dengan sibhul 'iddah. ${ }^{10}$

Tidak hanya dari segi Al-Qur'an, bisa juga dari hadis, seperti yang dilakukan oleh Faiq Ainurrofiq, bahwa dengan menggunakan double movement, ia berusaha untuk mengungkap ideal moral dari hadis yang menjelaskan tentang tidak akan berhasilnya kepemimpinan seorang perempuan. Menurutnya, hadis tersebut menjelaskan bahwa gagalnya kepemimpinan bukan didasarkan pada jenis kelamin, tapi rendahnya kapasitas leadership yang dimiliki seseorang. ${ }^{11}$

Maka dari itu, dalam hal ini peneliti mencoba untuk menawarkan hasil yang baru bahwa dengan menggunakan pendekatan tersebut tidak hanya dihasilkan hal-hal yang kongkret, seperti hasil penelitian di atas yang menghasilkan produk hukum. Tapi, dengan pendekatan ini, juga bisa didapatkan hasil yang justru bersifat transendental. Maka dari itu, untuk memecahkan permasalah tersebut, penulis mengunakan model penelitian secara kualitatif yakni analisa data yang berupa naratif bukan statistik, dan juga lebih menitikberatkan pada ranah deskripsi. ${ }^{12}$ Sedangkan metode penelitiannya adalah metode deskriptif analitik. Metode dengan cara menampilkan narasi deskriptif yang bersumber dari data yang digunakan. Menguraikan secara jelas argumen penelitian berdasarkan data. Metode pengumpulan data pada penelitian ini berupa metode dokumentasi.

Data tertulis menjadi rujukan utama, seperti halnya buku, dokumen, jurnal maupun artikel-artikel lainnya yang sesuai dengan pembahasan. Pada penelitian kualitatif, analisis dilakukan dengan cara mengatur data secara sistematis dan logis. ${ }^{13}$ Dan, jenis penelitiannya menggunakan pendekatan library research yaitu dengan cara mengumpulkan data kepustakaan baik itu buku, jurnal, artikel atau pun dokumen lain yang mendukung dengan penelitian ini.

\section{HERMENEUTIKA DOUBLE MOVEMENT FAZLUR RAHMAN}

Dalam penjelasan yang ditulis oleh Saeed, Fazlur Rahman berupaya untuk mengeksplor atau membebaskan pesan abadi Al-Qur'an, seperti yang diwahyukan di lingkungan yang konkrit dalam masyarakat yang melingkupi Nabi Muhammad Saw. dai Mekkah maupun Madinah. Maka, untuk mengadopsi makna tersebut hingga masa kini, Rahman menawarkan satu metode penafsiran kontekstual, yakni gerakan ganda (double movement). Berikut pernyataan Rahman yang dikutip langsung oleh Saeed:

Seseorang harus memahami proses impor atau makna dari pernyataan yang diberikan dengan mengkaji situasi historis atau masalah yang telah diberi

${ }^{10}$ Ahmad Ali Masyhuda, "Pengaplikasian Teori Double Movement Pada Hukum 'Iddah untuk Laki-Laki," Hermeneutika 4, no. 2 (2020), h. 12-26.

11 Faiq Ainurrofiq, "The Use of Hermeneutics Double Movement Fazlur Rahman in Comprehending Hadith of The Unsuccessful Leadership of Women," Jurnal Ushuluddin 27, no. 2 (2019), h. 132-44.

${ }^{12}$ A. Muri Yusuf, Metode Penelitian: Kuantitatif, Kualitatif, dan Penelitian Gabungan (Jakarta: Kencana, 2017), h. 331.

${ }^{13}$ M. Djunaidi Ghony dan Fauzan Almanshur, Metodologi Penelitian Kualitatif (Yogyakarta: arRuzz Media, 2012), h. 246. 
jawaban; (2) seseorang harus "melakukan generalisasi atas jawaban spesifik dan mengartikulasikannya sebagai pernyataan mengenai tujuan moral-sosial yang umum yag bisa "disaring" dari teks-teks spesfik dengan mempertimbangkan latar belakang sosia-historisnya"; (3) hal yang umum itu harus diwujudkan dalam konteks sosio-historis yang konkrit saat ini. ${ }^{14}$

Secara teoritis, double movement kemudian dikembangkan oleh Saeed sebagai metode yang kritis, komprehensif dan logis. Metode ini mampu memberikan pemahaman yang sistematis dan kontekstualis terhadap interpretasi Al-Qur'an. Double movement berarti gerakan ganda dalam interpretasi Al-Qur'an yaitu dengan cara menganalisis keadaan sekarang, kemudian keadaan Al-Qur'an pada masanya dan kembali lagi ke masa sekarang. ${ }^{15}$ Hal ini dilakukan untuk mendapatkan ideal moral dari suatu ayat ataupun surat Al-Qur'an agar bisa dikontekstualisasikan di masa saat ini. Sehingga, perintah-perintah dalam Al-Qur'an menjadi lebih hidup dan efektif kembali. ${ }^{16}$

Menurut Fazlur Rahman, Al-Qur'an adalah respon terhadap situasi tertentu, yang sebagian besarnya berkaitan dengan moral, agama dan pernyataan sosial yang menanggapi masalah spesifik. ${ }^{17}$ Hal ini menunjukkan bahwa konteks sejarah yang melingkupi Al-Qur'an sangat penting untuk dikaji. Sehingga, ini menjadi modal awal dalam kajian double movement.

Menurut Rahman, dalam gerakan pertama terdiri dari dua tahap; pertama, tahap memahami makna pernyataan dengan memeriksa situasi atau masalah historis di mana pernyataan teks adalah jawabannya. Konteks situasi ini termasuk konteks mikro dan makro. Konteks mikro lebih diarahkan ke situasi tertentu, sedangkan konteks makro mencakup situasi masyarakat, adat istiadat, lembaga, dan bahkan kehidupan di Semenanjung Arab pada saat turunnya teks. Langkah pertama dari gerakan pertama ini bertujuan untuk memahami makna teks secara keseluruhan maupun dalam batasbatas ajaran tertentu sebagai respons terhadap situasi tertentu. Kedua, menggeneralisasi jawaban spesifik dan membuat pernyataan yang memiliki tujuan moral-sosial umum. Ini "disaring" dari teks-teks tertentu dalam terang latar belakang sosial-historis dan rasio legis yang sering dinyatakan.

Gerakan kedua adalah proses pandangan umum untuk pandangan yang spesifik guna merumuskan dan mewujudkannya di kondisi sekarang. Pandangan umum diwujudkan dalam konteks sosial-historis saat ini. Untuk itu, diperlukan studi yang cermat tentang situasi saat ini dan analisis berbagai elemen komponen untuk menilai situasi saat ini dan membawanya ke situasi saat ini sejauh yang diperlukan untuk menentukan prioritas baru dan menerapkan nilai-nilai atau hadits Al-Qur'an di era sekarang. ${ }^{18}$

Singkatnya, langkah pertama dari metode ini adalah untuk mengeksplorasi makna kompatibilitas teks dengan konteks Al-Qur'an dan Hadis yang diungkapkan. Makna

\footnotetext{
${ }^{14}$ Saeed, Al-Qur'an Abad 21: Tafsir Kontekstual, Terj. Ervan Nurtawab, h. 44.

${ }^{15}$ Fazlur Rahman, Islam and Modernity: Transformation of an Intellectual Tradition (Chicago and London: Univercity Press, 1982), h. 3.

${ }^{16}$ Rifki Ahda Sumantri, "Hermeneutika Al-Qur'an Fazlur Rahman Metode Tafsir Double Movement," Jurnal Komunika 7, no. 1 (2013), h. 7-8.

${ }^{17}$ Rahman, Islam and Modernity: Transformation of an Intellectual Tradition, h. 5.

${ }^{18}$ Rahman, Islam and Modernity..., h. 6-7.
} 
teks harus dipelajari secara kronologis, diikuti dengan mengeksplorasi prinsip-prinsip umum teks melalui konteks sosio-kultural masyarakat Arab pada waktu itu. Gerakan kedua adalah memeriksa keadaan sosiologis masyarakat kontemporer berdasarkan prinsip-prinsip Al-Qur'an atau hadis. ${ }^{19}$

\section{ELABORASI SURAT AL-ANFĀL AYAT 17 BESERTA SELEKTIVITAS ASBĀB AN-NUZŪLNYA}

Untuk memulai gerakan pertama, penguraian secara mendalam terkait ayat 17 dalam surat al-Anfāl ini sangat perlu dilakukan. Hal ini bertujuan, untuk mendapatkan gambaran secara umum melalui tafsiran ayat yang ada.

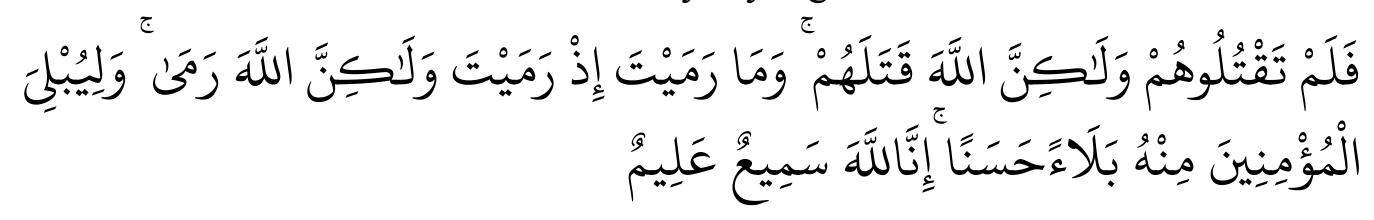

"Maka (yang sebenarnya) bukan kamu yang membunuh mereka, akan tetapi Allahlah yang membunuh mereka, dan bukan kamu yang melempar ketika kamu melempar, tetapi Allah-lah yang melempar. (Allah berbuat demikian untuk membinasakan mereka) dan untuk memberi kemenangan kepada orang-orang mukmin, dengan kemenangan yang baik. Sesungguhnya Allah Maha Mendengar lagi Maha Mengetahui,'(QS. al-Anfāl [8]: 17)

Dalam menjelaskan ayat ini, M. Quraish Shihab dalam tafsirnya mencoba untuk menghadirkan munasabah dari ayat sebelumnya yang mengandung perintah untuk perang dan larangan menghindar dari musuh. Maka, menjadi bersesuaian dengan ayat 17 sebab berlatar belakang dengan peristiwa perang, yakni Perang Badar. Tatkala peperangan itu terjadi -sekalipun perbandingan pasukan 1:3 dengan pasukan Quraishayat ini memberikan penegasan bahwa yang memenangkan kaum muslim atas kaum Quraish adalah kuasa dari Allah. Kemenangan yang diperoleh bukan semata-semata karena usaha dari kaum muslim, tapi ada campur tangan dari kehendak Allah.

Bukan kamu yang membunuh mereka, tapi Allah yang membunuh mereka dengan melibatkan para malaikat dalam peperangan dan menganugerahkan kepada Nabi Muhammad Saw. agar lemparannya tepat mengenai sasaran. Bukan engkau yang melempar, redaksi kalimat ini tidaklah menafikan usaha yang dilakukan oleh Nabi sendiri, terbukti dengan sambungan kalimat setelahnya ketika engkau melempar. Kalimat tersebut, menurut Quraish, untuk menghindari pemahaman secara majazi. Tapi yang menjadikan lemparan itu tepat pada obyeknya, karena Allah lah yang melempar, hingga menyebabkan kekalahan di pihak Quraish.

Allah menganugerahkan kepada kaum muslimin. Kata ليبلي terambil dari kata dasar بلاء yang memiliki arti menguji. Huruf lam tersebut berfungsï sebagai lam al-aqibah yang mengandung arti kesudahan, hasil atau pun akibat. Sedangkan kata ابلان berarti memberi anugerah. Pada mulanya kata ini bermakna sebagai ujian, namun kemudian digunakan untuk menunjukkan hasil, sehingga siapa pun yang mendapatkan hasil tersebut akan sanngat tersentuh dan terpengaruh. Hasil yang diperoleh biasanya sesuatu yang negatif, tapi tidak selalu demikian. ${ }^{r}$

${ }^{19}$ Ainurrofiq, "The Use of Hermeneutics Double Movement Fazlur Rahman in Comprehending Hadith of The Unsuccessful Leadership of Women", h. 136-37.

20 Lihat, Q.S. al-Anbiya’ (21): 35.

22 | Al-Fanar: Jurnal Ilmu Al-Qur'an dan Tafsir 
Ujian yang dimaksud dalam ayat ini adalah ikut serta dalam peperangan, sebab ujian tersebut digambarkan dengan ujian yang baik, maka hasilnya pun baik yaitu berupa kemenangan. Dari sisi-Nya, minhu kata ini berfungsi sebagai penekanan sekali lagi, bahwa kemenangan itu adalah anugerah yang baik yang berasal dari Allah. ${ }^{21}$

Terkait dengan Perang Badar yang disebut dengan hari pembeda, Sayyid Quṭ memiliki pandangan tersendiri, yang ada dalam tujuh poin argumennya, yakni:

1. Peristiwa Perang Badar adalah hari pembeda antara yang hak; kebenaran orisinil yang menjadi tegaknya langit dan bumi serta menjadi landasan tegaknya fitrah segala sesuatu yang bersumber dari keesaan Allah, dan batil; yang penuh dengan kebohongan dan kepalsuan. Sehingga, Perang Badar menjadi pembeda sempurna antara kebenaran yang sempurna dan kebatilan yang melampaui batas.

2. Merupakan pembeda antara keberanan dan kebatilan di dalam lubuk hatiyang dalam. Serta, membedakan antara tauhid yang murni dan mutlak dengan kemusyrikan dalam segala bentuknya, di dalamnya meliputi ubudiyah hati kepada selain Allah.

3. Membedakan antara ubudiyah kepada manusia; hawa nafsu, peraturan perundang-undangan, norma dan tata nilai, kebiasaan dengan sikap mengembalikan semuanya kepada Allah; tunduk hanya pada ketentuan-Nya.

4. Merupakanpembedaantara duafase sejarah pergerakan Islam. Yakni, fasekesabaran; penantian, ketabahan serta penghimpunan dengan fase kekuatan; pergerakan.

5. Merupakan pembeda antara dua periode sejarah manusia. Sebab, manusia secara keseluruhan memngalami perbedaan sebelum dan sesudah diberlakukannya aturan Islam.Bahkan,menurut Sayyid Quṭb, pengaruh tatananIslamtidakhanyaadadinegara muslim, tapijuga non-muslim. Menjadi pembeda antara dua sudut pandang terhadap unsur kemenangan dan unsur kekalahan. Secara lahiriah, unsur-unsur kemenangan itu ada di pihak kaum musyrikin sedang unsur kekalahan ada di pihak kaum muslim. Namun, Allah berkehendak menjadikan pasukan muslim yang minoritas tersebut sebagai pemenangnya. Hal ini untuk menunjukkan, bahwa kemenangan bukan semata perlengkapan senjata, namun lebih dari yakni kekuatan akidah.

6. Perang Badar adalah pembeda antara kebenaran dan kebatilan dengan indikasi yang lain. Kaum muslim yang awalnya keluar dari Madinah hanya untuk menghadang kafilah yang pimpin oleh Abu Shafyan, ternyata harus berhadapan dengan pasukan yang dibawa oleh Abu Jahal dengan persedian senjata yang lengkap. Yang pada mulanya tidak bermaksud untuk berperang, justru menjadi peristiwa pertempuran yangbersejarah. Halinimengisyaratkan bahwakebenarantidakakanadadankebatilan tidak akan lenyap, kecuali kebatilan itu dikalahkan oleh kekuatan kebenaran. ${ }^{22}$

Dari tafsiran ayat di atas, dapat disimpulkan bahwa ayat ini memang berkenaan dengan Perang Badar, seperti upaya Shihab yang mencoba untuk memunasabahkan dengan ayat sebelumnya. Kemudian, lebih lanjut Sayyid Quṭb memberikan keterangan terkait dengan makna Perang Badar.

\footnotetext{
${ }^{21}$ M. Quraish Shihab, Tafsir al-Misbah; Pesan, Kesan dan Keserasian Al-Qur'an, vol. 5 (Jakarta: Lentera Hati, 2002), h. 401-403.

${ }^{22}$ Sayyid Qutb, Tafsir Fi Dzilalil-Qur'an; di Bawah Naungan Al-Qur'an, Terj. As'ad Yasin, dkk, vol. 5 (Jakarta: Gema Insani, 2003), h. 199-201.
} 
Analisis Surat Al-Anfāl Ayat 17: Upaya Mengungkap Sisi Transendental Hermeneutika Double Movement

Langkah selajutnya adalah melihat cuplikan peristiwa yang terekam melalui periwayatan sabab nuzūl. Dari analisis yang dilakukan oleh peneliti, didapatkan hasil sebagai berikut:

Imam al-Suyuți dalam al-Dur al-Manthūr fì al-Tarfsīr al-Ma'thūr memaparkan 13 periwayatan. ${ }^{23}$ Peneliti mengklasifikasikan periwayatan tersebut dalam lima kategori, yakni:

a. Lima Riwayat menjelaskan pada peristiwa Perang Badar

$$
\begin{aligned}
& \text { وأخرج ابن أبي حاتم عن ابن زيد رضي الله عنه في قوله (وما رميت اذ رميت } \\
& \text { ولكن الله رمى) قال: هذا (ايوم بدر)", أخذ رسول الله صلى رئل الله عليه و و سلم } \\
& \text { ثلاث حصيات فرى بكصاة بين أظهرهم, فقال: شاهت الوجوه فانهزموا. }
\end{aligned}
$$

b. Tiga Riwayat menjelaskan pada peristiwa Perang Uhud

$$
\begin{aligned}
& \text { وأخرج ابن جربر و ابن المنذر عن الزهري رضي الله عنه في قوله (ووا رميت } \\
& \text { اذ رميت ولكن الله رى) , قال: حيث رمى أبي بن خلف أن ايوم أحد)" بحربته } \\
& \text { فقيل له: ان يك الاجحش, قال: أليس, قال: أنا أقتلك؟ بن و الله لو قالها لجميع } \\
& \text { الخلق لماتوا. }
\end{aligned}
$$

c. Tiga Riwayat menjelaskan kondisi saat perang terjadi, tanpa menyebutkan nama peristiwanya.

وأخرج ابن جربر عن محمد بن قيس و محمد بن كعب القرظي رضي الله

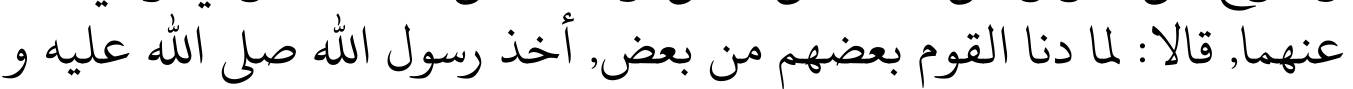
سلم قبضة من تراب فرمى بها في وجوه القوم و قال: شاهت الوجوه. فدخلت فب أعينهم كلهم, و أقبل أصحاب رسول الله صلى الله عليه و سلم يقتلونهم, وكان هزيمتهم فب رمية رسول الله صلى الله عليه و سلم, فأنزل الله (وما

$$
\text { رميت اذ رميت ولكن الله رىى) الى قوله (سميع عليم). }
$$

d. Satu Riwayat tanpa kejelasan dalam peristiwa apa.

وأخرج ابن جربر ابن أبي حاتم عن عبد الرحن بن جبير رضي الله عنه: ان

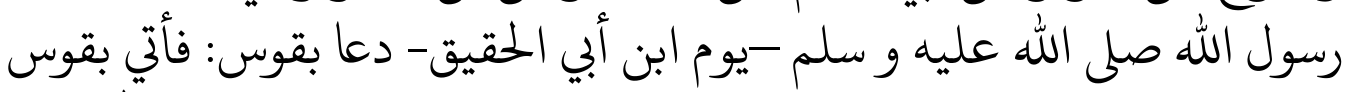
طويله, فقال: جيؤني بقوس غيرها. فجاءوه بقوس كيدا, فرى رسول الله صلى

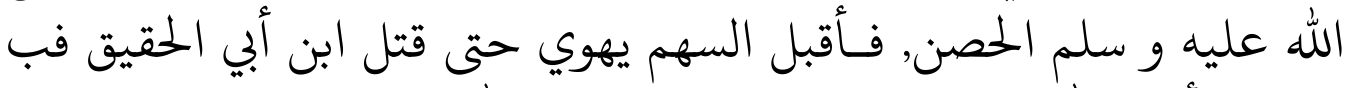

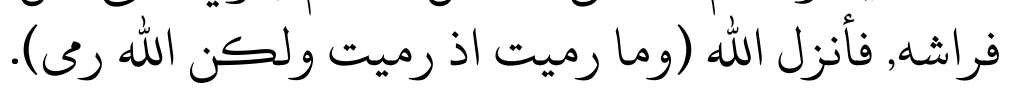

${ }^{23}$ Jalāl al-Dīn Al-Suyuṭi, al-Dur al-Manthūr fì al-Tarfsīr al-Ma 'thūr (Beirut: Dar al-Fikr, 1983), h. $39-41$.

24 | Al-Fanar: Jurnal Ilmu Al-Qur'an dan Tafsir 
e. Satu Riwayat yang penjelasannya lebih menekankan pada ibrah

$$
\begin{aligned}
& \text { وأخرج ابن اسحق و ابن أبي حاتم عن عروة بن الزبير رضي الله عنه في قوله } \\
& \text { (ولكن الله رمى) أي لم يكن ذون ذلك برميتك لولا الذي جعل الله تعالى من } \\
& \text { نصرك و ما ألقلى في صدور عدوك روكنها حتى هزمتهم (و ليبلي المؤمنين بلاء } \\
& \text { حسنا) أي يعرف آلمؤمنين من نعمته عليهم اظهارهم على عدوهم مح كثرة مثرة } \\
& \text { عدوهم و قلته عددهم, ليعرفوا بذلك حقه و يشكروا بذلك نعمته. }
\end{aligned}
$$

Sedangkan al-Wahidi hanya menyebutkan tiga periwayatan, sekaligus dengan status dari riwayat tersebut. ${ }^{24} \mathrm{Al}$-Wahidi juga menampilkan satu periwayatan berkenaan dengan peristiwa Perang Uhud, ${ }^{25}$ yang justru riwayat tersebut dishahihkan dan disepakati oleh al-Dhahabi, ada dalam al-Mustadrak Imam Hakim serta Lubāb al-Nuqūl al-Suyuṭi.

$$
\begin{aligned}
& \text { أخبرنا عبد الرحمن بن أحمد العطار, قال: حدثنا محمد بن عبد الله بن محمد } \\
& \text { البياع, قال: أخبرني إسماعيل بن محمد بن الفين الفضل الشعراني, قال: حدثني }
\end{aligned}
$$

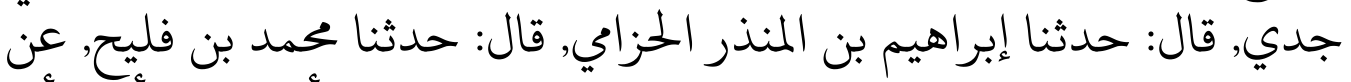

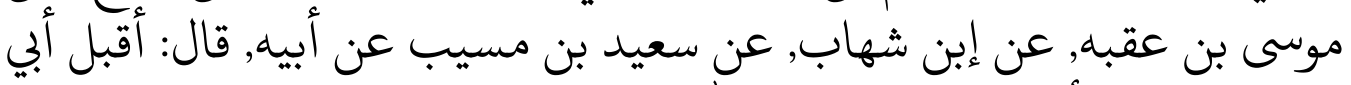

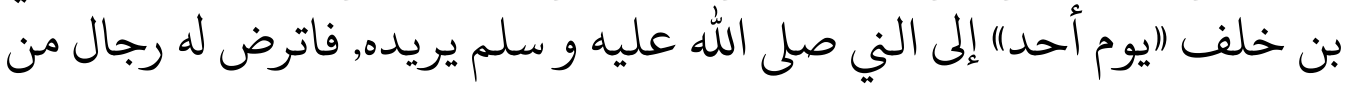

$$
\begin{aligned}
& \text { المؤمنين ... فأنزل الله تعالى في ذلك (وما رميت اذ رميت ولكن الله ركى). }
\end{aligned}
$$

Selain berkenaan dengan Perang Uhud, al-Wahidi juga mencatumkan periwayatan dengan status mursal, yang menjelaskan bahwa ayat ke 17 ini turun dengan latar belakang peristiwa pada saat Perang Khaibar.

$$
\begin{aligned}
& \text { وروى صفوان بن عمرو عن عبد الرحمن بن جبير: أن رسول الله صلى الله عليه } \\
& \text { و سلم "يوم خبير") دعا بقوس فأتي بقوس طويله ... فأنزل الله تعالى في ذلك (وما }
\end{aligned}
$$

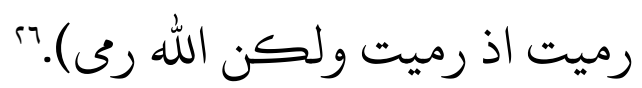

Namun demikian, al-Wahidi memberikan penegasan bahwa mayoritas pakar tafsir berpendapat bahwa ayat ini turun ketika Nabi Muhammad Saw. melempar segenggam kerikil saat Perang Badar, ${ }^{27}$ sambil berkata pada kaum musyrik "Rusaklah wajahmu!, Nabi melempar kerikil dan tidak tersisa mata mereka kecuali dimasuki dari bagian kerikil tersebut". Berikut riwayat yang berkaitan dengan Perang Badar dengan status isnadnya hasan.

${ }^{24}$ Ahmad Al-Wahidi, Asbāb al-Nuzūl (Beirut: Dar al-Kutub al-Ilmiah, 2009), h. 236-37.

25 A. Mujab Mahali, Asbabun Nuzul: Studi Pendalaman Al-Qur'an (Jakarta: Raja Grafindo Persada, 2002), h. 416-17.

${ }^{26}$ Hadis ini sama dengan yang dicatumkan oleh al-Suyuṭi dalam al-Dur al-Manthūr fì al-Tarfsīr al-Ma 'thūr (ada pada nomor 4 dalam penjelasan di atasnya). Hanya saja tidak disebutkan keterangan dalam "Perang Khaibar".

${ }^{27}$ Lihat Qutb, Tafsir Fi Dzilalil-Qur'an; di Bawah Naungan Al-Qur'an, Terj. As'ad Yasin, dkk, 5, h. 209. 


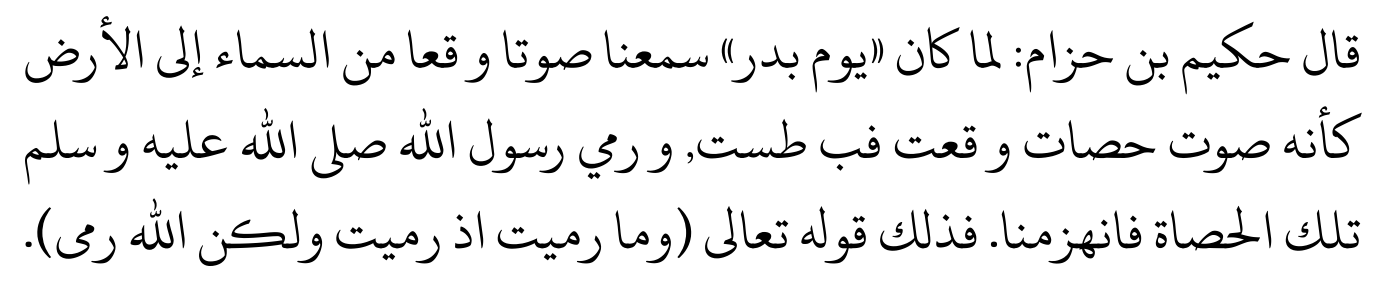

Dari beberapa uraian sabab nuzul di atas, data dan fakta sangat kuat mengindikasikan latar belakang dari ayat ini terjadi saat Perang Badar, dengan melihat ketersambungan ayat-ayat sebelum dan sesudahnya. Serta, ditambah dengan data pendukung tafsiran ayat sebelumnya.

\section{MENILIK ULANG SEJARAH PERANG BADAR}

Perang Badar merupakan pertempuran besar pertama yang terjadi dalam sejarah Islam, yakni perang antara umat Islam dengan kafir Quraish Mekkah. Perang ini terjadi 17 Maret $624 \mathrm{M}$ atau 17 Ramadhan $2 \mathrm{H}$. Dinamakan perang Badar, sebab terjadi di satu tempat yang bernama Badar. Secara perlengkapan senjata serta jumlah personil, pasukan muslim jauh tertinggal. Pasukan kaum muslim hanya berjumlah 313 orang, sedangkan pasukan Quraish berjumlah sekitar 1000 orang. ${ }^{28}$

Akar dari peperangan ini bermula ketika timbul rasa iri dan dengki dari kaum kafir Quraish sebab berkembang pesatnya kekuasaan Nabi di Madinah. Sehingga, mereka memperketat penjagaan kaum muslim yang masih bermukim di Mekkah, dengan tak segan-segan untuk menyiksa dan menekannya. Mereka telah menyiapkan pasukan besar sekaligus bersenjata lengkap untuk menyerang Madinah. Namun sebelumnya, mereka ingin memperolah simpati dari serta dukungan dari suku Arab non-muslim yang ada di sekitar Madinah. Bagaimana pun caranya, yang terpenting mereka berhasil menarik simpati dan menunjukkan kedigdayaan yang tak bisa ditandingi.

Salah satu cara yang dilakukan adalah dengan mengambil peluang jalur perdagangan menuju Syam yang akan melewati sekitar pantai Laut Merah. Sepanjang perjalan mereka memamerkan kebesarannya sembari menyebarkan kebencian terhadap kaum muslim. Kafilah ini dimpimpin oleh Abu Shafyan dengan dijaga 30-40 orang lainnya. Mendengar hal ini, Rasul kemudian mengutus salah seorang untuk memastikan. ${ }^{29}$

Meskipun terbesit dalam diri Rasul, khawatir jika kaum Anshar tidak mau menolongnya. Kemudian Rasul mengambi sumpah kepada kaum Muhajirin dan Anshar terkait peperangan ini. Kaum Anshar pun dengan menjawab tanpa keraguan, bahwa mereka akan membatu Rasul dalam peperangan ini. Mereka mengatakan, "kami bersamamu ya Rasulullah. Demi Dzat yang mengutus engkau dengan kebenaran. Jika engkau meminta kami tenggelam bersamamu di laut, kami akan mengikutinya". ${ }^{30}$

Pada tanggal 12 Ramadhan, Nabi bersama sahabat berangkat 313 orang berangkat menghadang kafilah Abu Shafyan untuk mengambil harta yang dibawanya. Nabi

${ }^{28}$ Pada awalnya, jumlah pasukan Quraish sebanyak 1300 orang. Namun, 300 di antara mereka kembali ke Mekkah, sehingga jumlahnya menjadi 1000. Lihat, Safi Al-Rahman Mubarakfuri, alRahiq al-Makhtum Bahthu fi al-Sirah al-Nabawiyah, Terj. Abdullah Hadar (Riyad: Kantor Dakwah Bagi Pendatang, 2005), h. 89.

${ }^{29}$ Akhmad Saufan, "Strategi dan Diplomasi Perang Rasulullah,” Jurnal Lektur Keagamaan, Vol. 13, No. 1 (2015), h. 114.

${ }^{30}$ Said Ramadhani Al-Buṭi, Fikh al-Sirah al-Nabawiyah (Suriyah: Dar al-Fikr, 2011), h. 157. 
berangkat tanpa adanya niatan untuk berperang. Ketika Nabi memerintah dua matamata untuk mencari informasi terkait kafilah dagang tersebut, ternyata diketahui oleh Abu Shafyan. Sehingga, Abu Shafyan mengirim utusan ke Mekkah untuk menyiapkan pasukan.

Orang yang diutus Abu Shafyan adalah Dhamdham bin Amr al-Ghifarri, ${ }^{31}$ yakni orang yang pandai bersilat lidah. Ia pun menyebarkan informasi yang berlebihan sehingga menyulut kemarahan dari pemuka Quraish, terutama Abu Jahal. Pemberitaan ini mulai simpang-siur ketika Abu Shafyan mengirim surat bahwa ia dan kafilahnya baik-baik saja. Hal ini membuat Abu Jahal semakin marah dan tetap memutuskan untuk pergi ke Badar, seraya bersumpah bahwa ia tidak akan kembali sebelum ke Badar. ${ }^{32}$ Mengetahui kondisi yang demikian, Nabi pun mengadakan musayawarah dengan para sahabat, terutama kaum Anshar. Ketika para sahabat menyetujuinya, Nabi terus mencari informasi sembari menyusun strategi.

Setelah kaum Quraish tiba di Badar, mereka sempat berselisih pendapat. Utbah bin Rabi'ah berpendapat bahwa tidak pantas untuk melakukan peperangan. Sebab, tidak ada bukti terjadi perampasan maupun penyerangan atas kafilah Abu Shafyan. Namun, Abu Jahal terus menghasut untuk melakukan peperangan dan mengejek Utbah bin Rabi'ah yang enggan ikut serta. Akhirnya, Utbah termakan dengan ucapan Abu Jahal. Ia pun mengajak anak serta saudaranya dalam peperangan. Ketiganya tewas dalam satu lawan satu.

Perang pun dimulai antar dua pasukan. Di tengah medan pertempuran itu, Nabi memanjatkan doa: "Ya Allah, bila kelompok ini (Kaum Muslimin) kalah pada hari ini, maka engkau tidak akan lagi disembah". ${ }^{33}$

Nabi mengambil segenggam kerikil dan melemparnya ke arah kaum Quraish. Singkat cerita, peperangan itu berlanjut dan dimenangkan oleh kaum Muslim. ${ }^{34}$

\section{IDEAL MORAL AYAT ETHICO-LEGAL: ANTARA KONKRET DAN TRANSENDENTAL}

Seperti dalam uraian-uraian di atas, bahwa dalam tulisan ini, ayat yang dikaji berkaitan dengan konteks peperangan, yakni perang Badar. Secara konteks mikro seperti dalam kajian periwayatan sabab nuzul, sedangkan konteks makronya meliputi telaah bagaimana kondisi saat peperangan, politik dan sosialnya.

Jika ditelaah dari keadaan sosialnya, hijrahnya Nabi Muhammad ke Madinah, karena Nabi dan pengikutnya mengalami tekanan, pendiskriminasian dan lain sebagainya

\footnotetext{
${ }^{31}$ Mubarakfuri, al-Raḥiq al-Makhtum Baḥthu fì al-Sirah al-Nabawiyah, Terj. Abdullah Hadar, h. 85 .

${ }^{32}$ Mubarakfuri, al-Rahiq al-Makhtum, h. 85.

${ }^{33}$ Dalam data sejarah yang lain, disebutkan juga Nabi berdoa di detik-detik pertempuran akan dimulai, di sebuah kemah kecil dengan air mata berlinang. "Ya Allah, akankah Engkau mencelakakan pasukan kecil orang-orang beriman ini menjadi binasa hari ini. Jika demikian, tak akan ada seorang pun di bumi ini yang akan menyembah Engkau dan mengemban risalah-Mu ke dunia”. Lihat, Maulana Muhammad Ali, Biografi Muhammad Rasulullah, Terj. S.A Syurayuda (Jakarta: Turos, 2015), h. 144.

${ }^{34}$ Muhammad Zulfahar Hilmi Rahmadani, "Pengaruh Perang Badar Terhadap Eksistensi Kaum Muslim di Madinah," Skripsi, UIN Sunan Ampel Surabaya, 2019, h. 19-31.
} 
yang menyebabkan ketersiksaan. Kemudian Nabi diterima baik di Madinah dan Nabi pun membangun serta mengembangkan peradaban Islam di sana. Sebab semakin berkembang pesatnya ajaran Islam di Madinah, orang kafir Quraish merasa tersaingi. Mereka khawatir posisinya akan tergeser dengan Islam. Oleh karena itu, mereka terus berupaya untuk menghancurkan Islam dengan cara apa pun.

Perang Badar seharusnya menjadi momentum yang membanggakan bagi kaum kafir Quraish, seperti yang mereka bayangkan. Sebab, sangat tidak rasional jika mereka mengalami kekalahan, melihat jumlah pasukan yang banyak dan persenjataan yang lengkap. Namun, kenyataan berbanding terbalik dengan angan-angan mereka. Pertempuran itu justru dimenangkan oleh kaum muslim yang hanya berjumlah 313 orang dengan perlengkapan seadanya.

Kemenangan yang berpihak kepada Nabi Muhammad menjadi semacam modal awal untuk membangun kekuatan Islam. Sebab, secara tampak, sangat mustahil pasukan Nabi memenangkan pertempuan tersebut. Dan dengan kemenangan itu, sukusuku yang lain, terutama yang berada di kawasan Madinah menjadi segan kepada kaum muslim. Bahkan, tidak sedikit dari mereka yang kafir lalu berbondong-bondong masuk Islam. Keadaan itu, menjadikan kekuatan Islam semakin bertambah dan posisi Nabi di Madinah sangat dihormati dan diperhitungkan. Sehingga, Islam tidak hanya kuat secara militer, tapi juga secara politik serta berkelas secara sosial. Seperti yang ditulis oleh Philip K. Hitti,

Dan, di Madinah, setelah Perang Badar, Islam berubah menjadi lebih dari sekadar agama negara, Islam merupakan negara itu sendiri. Sejak saat itu, dan bermula dari sanan, Islam menjadi seperti apa yang dikenal dunia saat ini, sebuah institusi militan. ${ }^{35}$

Selain dari segi militer, politik dan sosial, keberhasilan dalam peperangan ini juga berdampak pada sisi spiritualnya. Kepercayaan atau keimanan dari kaum muslim semakin bertambah, serta diikuti oleh semakin banyaknya para pengikut ajaran Islam. Sedangkan pada diri kafir Quraish, mereka mengalami ketakutan dan kelemahan mental. Selain itu, keadaan tersebut bisa juga ditelaah dari segi ekonominya. Perekonomian kaum muslim juga semakin stabiil, yakni didapatkan dari ghanimah-ghanimah. Serta, sejumlah harta yang digunakan oleh mereka yang ingin menebus para tawanan. ${ }^{36}$

Dari uraian di atas, untuk mengambil ideal moral dari ayat ini penulis mengambil satu rangkaian peristiwa, dimulai dari teks ayat menuju konteks dengan terma garis penghubung "perang". Nabi keluar dari Madinah hanya untuk menghadang kafilah dagang yang dipimpin oleh Abu Shafyan, yang mungkin saja di antara barang dagangan tersebut ada harta dari kaum muslim yang masih bermukin di Mekkah. Tanpa adanya niatan untuk melakukan peperangan. Namun, peperangan itu harus ditanggapi oleh Nabi, sebab Nabi dan pasukannya tengah berada dalam keadaan yang mengharuskan mereka untuk berperang. Maksudnya, perang itu boleh dilakukan ketika dalam keadaan darurat dan tertekan.

Seperti yang dijelaskan oleh Wahbah Zuhaili bahwa, Nabi Muhammad mengumumkan bahkan melegalkan perang hanya untuk membela hak-hak asasi manusia,

\footnotetext{
${ }^{35}$ Philip K. Hitti, History of The Arabs, Terj. R. Cecep Lukman Yasin dan Dedi Slamet Riyadi (Jakarta: Serambi, 2010), h. 146-147.

${ }^{36}$ Rahmadani, "Pengaruh Perang Badar Terhadap Eksistensi Kaum Muslim di Madinah,", h. $50-58$.
} 
seperti hak hidup, proteksi, perlakuan adil, kebebasan dan hak kehormatannya. ${ }^{37}$

Dengan ayat ini pula, di dalamnya memberikan hikmah yang begitu dalam. Bahwa, sebaiknya menjadi seorang muslim itu harus beriman dan berserah diri kepada Allah. Sebab, Allah bisa menjadikan nyata setiap apa yang dianggap mustahil oleh manusia. Seperti halnya dalam peristiwa kemenangan kaum muslim dalam peperangan ini.

\section{PENUTUP}

Hermenutik double movement memang digunakan untuk menganalisis ayat-ayat hukum sehingga menghasilkan ideal moral yang bersifat konkret. Terlebih dengan ayat-ayat perang, seperti halnya dalam tulisan kali ini. Dalam pandangan peneliti, Al-Qur'an selalu memiliki sisi hikmah yang terkadang tidak bisa dinalar. Maka dari itu, seharusnya di balik ayat-ayat perang ini, tetap ada sisi hikmah yang sifatnya transendental.

Ideal moral yang bersifat konkret dari ayat ini adalah dibolehkan bahkan diharuskan mengambil jalur peperangan jika sudah dalam keadaan darurat dan tertekan. Seperti, adanya tekanan, pendiskriminasian dan lain sebagainya yang menyebabkan ketersiksaan. Dan, ideal moral yang bersifat transendental adalah harus adanya sikap tawakal dan ikhtiar dari setiap muslim sebagai bukti keberserahdiriannya kepada Allah atas ketidakberdayaan dirinya. Bahwa Allah dapat menjadikan nyata setiap apa yang dianggap mustahil oleh manusia.

\section{DAFTAR PUSTAKA}

Abdul Karim, Abdurrahman bin. Kitab Sejarah Nabi Muhammad SAW. Yogyakarta: DIVA Press, 2013.

Ainurrofiq, Faiq. “The Use of Hermeneutics Double Movement Fazlur Rahman in Comprehending Hadith of The Unsuccessful Leadership of Women." Jurnal Ushuluddin, Vol. 27, No. 2, (2019).

Aisyah, Aas Siti. "Reinterpretasi Ayat-Ayat Qisas dengan Metode Double Movement." Skripsi UIN Sunan Gunung Djati Bandung, 2019.

Ali, Maulana Muhammad. Biografi Muhammad Rasulullah, Terj. S. A Syurayuda. Jakarta: Turos, 2015.

Buți (Al), Said Ramadhani. Fikh al-Sirah al-Nabawiyah. Suriyah: Dar al-Fikr, 2011.

Chirzin, Muhammad. Mengerti Asbabun Nuzul; Rampai Peristiwa dan pesan Moral di Balik Ayat-Ayat Suci Al-Qur'an. Jakarta: Zaman, 2015.

Ghony, M. Djunaidi, dan Fauzan Almanshur. Metodologi Penelitian Kualitatif. Yogyakarta: arRuzz Media, 2012.

Haq, Muhammad Faishal, dan Miatul Qudsia. "Revitalisasi Hermeneutika Sebagai Pendekatan Tafsir (Kajian Hermeneutika Abdullah Saeed).” Miyah: Jurnal Studi Islam, Vol. 16, No. 1, (2020).

${ }^{37}$ Ini merupakan pernyataan yang disampaikan oleh Zuhaili dalam disertasi doktoralnya. Lihat, Misbakhul Khaer, "Etika dan Hukum Perang pada Masa Peperangan Nabi Muhammad SAW," Jurnal Qolamuna 2, no. 1 (2016): 7. 
Analisis Surat Al-Anfāl Ayat 17: Upaya Mengungkap Sisi Transendental Hermeneutika

Double Movement

Hitti, Philip K. History of The Arabs, Terj. R. Cecep Lukman Yasin dan Dedi Slamet Riyadi. Jakarta: Serambi, 2010.

Khaer, Misbakhul. "Etika dan Hukum Perang pada Masa Peperangan Nabi Muhammad SAW.” Jurnal Qolamuna, Vol. 2, No. 1, (2016).

Mahali, A. Mujab. Asbabun Nuzul: Studi Pendalaman Al-Qur'an. Jakarta: Raja Grafindo Persada, 2002.

Masyhuda, Ahmad Ali. "Pengaplikasian Teori Double Movement Pada Hukum 'Iddah untuk Laki-Laki." Hermeneutika, Vol. 4, No. 2, (2020).

Mubarakfuri, Safi Al-Rahman. al-Rahiq al-Makhtum Bahthu fi al-Sirah al-Nabawiyah, Terj. Abdullah Hadar. Riyad: Kantor Dakwah Bagi Pendatang, 2005.

Muttaqin, Labib. "Aplikasi Teori Double Movement Fazlur Rahman Terhadap Doktrin Kewarisan Islam Klasik." Al-Manahij; Jurnal Kajian Hukum Islam 7, no. 2 (2013).

Nadia, Zunly. "Membaca Ayat Poligami Bersama Fazlur Rahman.” Mukaddimah: Jurnal Studi Islam, Vol. 2, No. 2, (2018).

Quṭb, Sayyid. Tafsir Fi DzilalilQur'an; di Bawah Naungan Al-Qur'an, Terj. As'ad Yasin, dkk. Vol. 5. Jakarta: Gema Insani, 2003.

Rahmadani, Muhammad Zulfahar Hilmi. "Pengaruh Perang Badar Terhadap Eksistensi Kaum Muslim di Madinah.” Skripsi, UIN Sunan Ampel Surabaya, 2019.

Rahman, Fazlur. Islam and Modernity: Transformation of an Intellectual Tradition. Chicago and London: Univercity Press, 1982.

Riyani, Irma. "Reinterpretasi Asbāb al-Nuzūl bagi Penafsiran Al-Qur'an", Wawasan: Jurnal Ilmiah Agama dan Sosial Budaya, Vol. 2, No. 1, (2017).

Saeed, Abdullah. Paradigma, Prinsip dan Metode Penafsiran Konteksualis Al-Qur'an, Terj. Lien Iffah Naf'atu Fina dan Ari Henri. Yogyakarta: Baitul Hikmah Press, 2017.

—. Pengantar Studi Al-Qur'an. Yogyakarta: Baitul Hikmah Press, 2016.

. Al-Qur'an Abad 21: Tafsir Kontekstual, Terj. Ervan Nurtawab. Bandung: Mizan, 2016.

-. Pengantar Studi Al-Qur'an, Terj. Shulkhah dan Sahiron Syamsudin. Yogyakarta: Baitul Hikmah Press, 2016.

Saufan, Akhmad. "Strategi dan Diplomasi Perang Rasulullah." Jurnal Lektur Keagamaan Vol. 13, No. 1 (2015).

Shihab, M. Quraish. Tafsir al-Misbah; Pesan, Kesan dan Keserasian Al-Qur'an. Vol. 5. Jakarta: Lentera Hati, 2002.

Sumantri, Rifki Ahda. "Hermeneutika Al-Qur'an Fazlur Rahman Metode Tafsir Double Movement,." Jurnal Komunika Vol. 7, No. 1, (2013).

Suyuți (Al), Jalāl al-Dīn. al-Dur al-Manthūr fì al-Tarfsīr al-Ma 'thūr. Beirut: Dar al-Fikr, 1983.

Wahidi (Al), Ahmad. Asbāb al-Nuzūl. Beirut: Dar al-Kutub al-Ilmiah, 2009.

Yusuf, A. Muri. Metode Penelitian: Kuantitatif, Kualitatif, dan Penelitian Gabungan. Jakarta: Kencana, 2017. 